\title{
sciendo
}

\section{High prolidase levels in patients with Familial Mediterranean Fever (FMF)}

\author{
MELIHA BAYRAM ${ }^{1}$, MEHMET EMIN DERIN ${ }^{2}$, HALEF OKAN DOĞ $\breve{N}{ }^{3}$, \\ GÖKMEN ASAN ${ }^{1}$, MEHTAP ŞAHIN $^{3}$, ALI ŞAHIN ${ }^{2}$ \\ ${ }^{1}$ Department of Internal Medicine, Cumhuriyet University, Faculty of Medicine, Sivas, Turkey \\ ${ }^{2}$ Department of Internal Medicine - Rheumatology, Cumhuriyet University, Faculty of Medicine, Sivas, Turkey \\ ${ }^{3}$ Department of Biochemistry, Cumhuriyet University, Faculty of Medicine, Sivas, Turkey
}

\begin{abstract}
Introduction. Familial Mediterranean Fever (FMF) is an autoinflammatory disease. Prolidase is a specific imidodipeptidase that plays a role in collagen degradation, and an important role in inflammation and wound healing. Hypoxia-inducible factor-1 $\alpha$ (HIF-1) is an important protein in the regulation of immunological response, hemostasis, vascularization. The aim of the study was to compare serum prolidase and HIF-1 $\alpha$ levels in patients with FMF in attack-free period and healthy control group.

Methods. Between August 2017 and December 2017, sixty patients diagnosed with FMF according to the criteria of the Tel-hashomer and admitted to Sivas Cumhuriyet University Medical Faculty, Internal Medicine Rheumatology Department and sixty healthy volunteers were enrolled in the study.

Results. Median serum prolidase levels were 72.1 (25.1-114.9) $\mathrm{ng} / \mathrm{ml}$ in FMF group and 30.7 $(21.3-86.2) \mathrm{ng} / \mathrm{mL}$ in healthy control $(\mathrm{HC})$ group $(\mathrm{p}=0.018)$. ROC analysis showed that the sensitivity was $65 \%$ and the specificity was $68.3 \%$ at serum prolidase levels $54.03 \mathrm{ng} / \mathrm{mL}(\mathrm{p}<0.05)$. The median serum levels of HIF-1 $\alpha$ in the FMF group was $482.0(292.0-3967.0) \mathrm{pg} / \mathrm{mL}$ and 632.0 $(362.0-927.0) \mathrm{pg} / \mathrm{mL}$ in the $\mathrm{HC}$ group $(\mathrm{p}>0.05)$. There was no significant correlation between laboratory findings, sex, age, and prolidase $(\mathrm{p}>0.05)$.

Conclusion. Serum prolidase enzyme levels in FMF patients with attack-free period were significantly higher than in the HC group. However, the role of prolidase and HIF1- $\alpha$ in the FMF disease needs to be clarified with more extensive and comprehensive studies.
\end{abstract}

Key words: Familial Mediterranean Fever (FMF), prolidase, HIF-1 $\alpha$.

\section{INTRODUCTION}

Familial Mediterranean Fever (FMF) is an auto-inflammatory disease and it has been shown that uncontrolled interleukin (IL) $1 \beta$ secretion plays a role in its pathogenesis with the activation of caspase-1 from cells such as neutrophils, monocytes and macrophages $[1,2]$. Prolidase is a cytosolic exopeptidase which cleaves the iminodipeptides containing proline or hydroxyproline at the C-terminal [3]. In a few studies in which the prolidase enzyme activity was assessed, it has been shown that enzyme activity increases due to collagen degradation in diseases with chronic inflammation [3]. Hypoxiainducible factor-1 (HIF-1) $\alpha$ is a dimeric protein complex that plays a complementary role in the body's response to low oxygen concentration (response to hypoxia) [4]. HIF-1 is an important protein involved in the regulation of immunological response, hemostasis, vascularization and anaerobic metabolism [4]. While hypoxia-inducible factors (HIFs) are known to control T cells and macrophage activation, their function in B lymphocytes has not yet been clearly identified. In macrophages, HIF-1 $\alpha$ enhances cell motility, and allows the release of pro-inflammatory cytokines $[5,6]$. Recent studies have shown that HIF-1 $\alpha$ has an important role in the function of $\mathrm{T}$ helper cells $(\mathrm{Th})$, regulatory $\mathrm{T}$ cells (T-reg), and Dendritic Cells (DCs) [7]. In our study, we aimed to compare Prolidase and HIF-1 $\alpha$ levels in patients with FMF and healthy individuals.

\section{MATERIALS AND METHODS}

\section{PATIENTS}

Patients who were admitted to Cumhuriyet University Faculty of Medicine (CUFM) Hospital Department of Internal Medicine-Rheumatology outpatient clinic between August 2017 and February 2018 and who were diagnosed with FMF according to Tel-Hashomer criteria but in attack-free period (at least 2 weeks after the last attack) were included in our study. All of FMF patients were under treatment of colchicine (1-2 mg). These patients had applied to 
the hospital for routine control. The healthy subjects included in the control group were selected among the individuals who applied to CUFM Hospital Department of Internal Medicine-General Internal Medicine outpatient clinic for the purpose of check-up. They didn't have any active or chronic disease. Sixty patients with FMF and sixty healthy subjects who met the inclusion criteria were included in the study after reading the subject information form and after signing the informed consent form for those who agreed to participate in the study. The disease severity score defined by Pras was used. Parameters in PRAS scoring were as onset age of disease, number of attack at a month, arthritis, erysipelas like erythema, amylodosis and dose of colchicine. According to PRAS scoring a score of 3 to 5 were reflected mild disease, a score of 6-8 mild-to-moderate disease, and a score of $>9$ severe disease.

\section{MAIN OUTCOME VARIABLES}

Demographic characteristics of subjects with FMF and healthy controls as well as information on their diagnoses, diseases courses and treatments were obtained from the patient files and by one-toone interviews with patients. In addition, laboratory parameters of the patients and information on the treatments they received were recorded. The blood samples were taken from a peripheral vein into suitable tubes, and centrifuged at $5000 \mathrm{G}$ for 15 minutes and stored in an Eppendorf tube at $-80^{\circ} \mathrm{C}$. Thereafter, the samples were studied by ELISA method in CUFM Division of Biochemistry. SinoGeneClon $\mathbb{R}$ Prolidase ELISA Kit and Thermo Fisher ${ }^{\circledR}$ HIF-1 ALPHA ELISA Kit were used for measuring Serum Prolidase enzyme levels and HIF- $1 \alpha$ levels, respectively. The routine examination findings of patients, MEFV gene (a total of 12 mutations in exon 2 and exon 10 were examined by medical genetic department), creatinine, ALT, AST, Fibrinogen, $\mathrm{C}$ reactive protein (CRP), Hemogram parameters, Erythrocyte Sedimentation Rate (EsR) were recorded retrospectively.

\section{PROCEDURES}

For our study, ethics committee approval was obtained from CUFM Clinical Trials Ethics Committee with the decision dated 11.07.2017 and numbered 2017-07/28. The study was conducted in accordance with the principles of the Helsinki Declaration of World Medical Association.

\section{STATISTICAL ANALYSIS}

Statistical assessments were performed using SPSS 22 (Statistics Program for Social and Science) software. Whether the data showed normal distribution was evaluated using histogram, q-q plots and ShapiroWilk test. The homogeneity of variance was tested by the Levene's test. For two-group comparisons, Mann-Whitney $U$ test and two independent sample t-tests were used for quantitative variables. For comparisons of more than two groups, one-way analysis of variance and Kruskal-Wallis tests were performed. Pearson $\chi^{2}$ analysis was used to compare categorical data. Tukey's test and Dunn-Bonferroni test were performed for multiple comparisons. The correlation between quantitative data was evaluated via Spearman correlation analysis. ROC (Receiver operating characteristics) analysis was used to investigate the estimations of prolidase and HIF1- $\alpha$ variables on FMF status. The area under the ROC curve were calculated with a $95 \%$ confidence interval. The cut-off values for each marker were calculated with Youden's index. Sensitivity, specificity, positive predictive and negative predictive values for optimum cut-of values were in the $95 \%$ confidence interval. The significance level was considered as $p<0.05$.

\section{RESULTS}

In our study, 60 patients with FMF and 60 healthy controls were included. Age and gender characteristics were similar in both groups (Table 1). There was no significant difference between the two groups in terms of serum creatinine, Platelet, WBC (White Blood Cell), Fibrinogen, Neutrophil, Lymphocyte and MPV (Mean Platelet Volume) values, and Neutrophil lymphocyte ratio (N/L). In the patient group ESR and CRP levels were significantly higher than healthy groups (Table 1).

In the MEFV gene mutation analysis; homozygous M694V mutation was detected in 12 (20\%) people, heterozygous M694V in 27 (45\%) people, Heterozygous E148Q in 7 (11.6\%) people, Heterozygous V726A in 5 (8.3\%) people, Heterozygous R202Q in $3(5 \%)$ people, Heterozygous M680I in $3(5 \%)$ people and $\mathrm{V} 761 \mathrm{H}$ in $1(1.66 \%)$ person. No mutation was detected in the MEFV gene in 2 $(3.33 \%)$ patients. All of FMF patients were under treatment of colchicine (1-2 mg). Three patients were under anti-IL-1 treatment. Two patients had amyloidosis (Table 2). 
Table 1

Demographic data and laboratory values

\begin{tabular}{|c|c|c|c|}
\hline & $\begin{array}{l}\text { FMF Patient Group } \\
(\mathbf{n}=60)\end{array}$ & $\begin{array}{l}\text { Healthy Control Group } \\
\qquad(\mathrm{n}=60)\end{array}$ & $\mathbf{p}$ \\
\hline Male & $33(55 \%)$ & $30(50 \%)$ & \\
\hline Female & $27(45 \%)$ & $30(50 \%)$ & 0.583 \\
\hline Age & 33 years $(16-60)$ & 34 years $(21-42)$ & 0.231 \\
\hline Neutrophil (\%) (6-8) & $62.27(52,2-100,3)$ & $60.31(42,2-85,3)$ & 0.238 \\
\hline Lymphocyte (\%) (2-3) & $29.2(20,-34,62)$ & $31.49(26,3-43,2)$ & 0.127 \\
\hline $\mathrm{N} / \mathrm{L}$ & $2.2(1.5-2.9)$ & $1.9(1.5-2.4)$ & 0.091 \\
\hline Hemoglobin (g/dL) (13-17) & $13.87 \pm 1.80$ & $14.92 \pm 1.65$ & $0.001^{*}$ \\
\hline Platelet (ul) $\left(\mathrm{x10}^{3}\right)(200-400)$ & $260.47 \pm 71.30$ & $273.82 \pm 70.36$ & 0.304 \\
\hline $\log (W B C)(f l) \times 10^{3}(3,5-6)$ & $3.8(3.8-3.9)$ & $3.9(3.8-3.9)$ & 0.431 \\
\hline Creatinine mg/dL $(0,6-1)$ & $0.7(0.6-0.9)$ & $0.8(0.7-0.9)$ & 0.121 \\
\hline MPV $(8-10)$ & $9.5(8.9-10.4)$ & $9.6(8.8-10.5)$ & 0.795 \\
\hline ESR mm/hr (0-20) & $10.0(5.0-26.5)$ & $7.5(4.0-10.0)$ & $0.003^{*}$ \\
\hline CRP mg/dL (0-8) & $3.9(2.2-8.9)$ & $3.0(1.9-4.0)$ & $0.011^{*}$ \\
\hline Fibrinogen mg/dL (200-400) & $326.0(266.3-412.3)$ & $284.0(265.0-336.3)$ & 0.227 \\
\hline
\end{tabular}

Values were presented as mean ( \pm standard deviation), median (minimum-maximum), $\% \mathrm{n}$.

*: $\mathrm{p}<0.05$ Mann Whitney U, and Student-t tests were used.

Table 2

Distribution of MEFV genetic mutations and clinical features in FMF Patient Group

\begin{tabular}{|c|c|}
\hline Features & Explanation \\
\hline Genotype & Number of cases $(\%)$ \\
\hline Homozygous M694V & $12(20 \%)$ \\
\hline Heterozygous M694V & $27(45 \%)$ \\
\hline Heterozygous E148Q & $7(11.6 \%)$ \\
\hline Heterozygous M680I & $3(5 \%)$ \\
\hline Heterozygous V726A & $5(8.3 \%)$ \\
\hline Heterozygous R202Q & $3(5 \%)$ \\
\hline Heterozygous R761H & $1(1.6 \%)$ \\
\hline No mutation & $2(3.3)$ \\
\hline Age of diagnosis & Median 18 years (min:4 - max:40) \\
\hline Number of attack & $\begin{array}{l}<1 / \text { month } \mathrm{n}: 56 \\
>2 / \text { month } \mathrm{n}: 4\end{array}$ \\
\hline PRAS score & $\begin{array}{l}\mathrm{n}: 39(65 \%) \text { (mild) } \\
\mathrm{n}: 17(29 \%) \text { (mild-moderate) } \\
\mathrm{n}: 4(6 \%) \text { (severe) }\end{array}$ \\
\hline Amyloidosis & n: $2(3 \%)$ \\
\hline Colchicine dose & $\begin{array}{l}\mathrm{n}: 36(60 \%) 1 \mathrm{mg} / \text { day } \\
\mathrm{n}: 15(25 \%) 1,5 \mathrm{mg} / \text { day } \\
\mathrm{n}: 9(15 \%) 2 \mathrm{mg} / \text { day }\end{array}$ \\
\hline Co-morbidities (hypertension, diabetes mellitus, etc) & $\mathrm{n}: 0(0 \%)$ \\
\hline Biologic drug (anti-IL-1) & $\mathrm{n}: 3(5 \%)$ \\
\hline
\end{tabular}

\section{SERUM PROLIDASE}

AND HIF-1 ALPHA LEVELS

The median serum prolidase level was 72.1 (25.1-114.9) ng/mL in FMF group and 30.7 (21.386.2) $\mathrm{ng} / \mathrm{mL}$ in control group. There was a statistically significant difference between the two groups $(\mathrm{p}=0.018)$ (Figure 1$)$.

The mean serum HIF-1 $\alpha$ level was 482.0 (292.0-3967.0) $\mathrm{pg} / \mathrm{mL}$ in the FMF group, and $632.0(362.0-927.0) \mathrm{pg} / \mathrm{mL}$ in the control group.
There was no statistically significant difference between the two groups $(\mathrm{p}=0.434)$.

When prolidase values were compared between both groups, ROC Curve analysis was performed because the difference was statistically significant (Figure 2). Since prolidase had distinctive characteristics, cut-off value was determined according to Youden's index. This value was determined to be $54.03 \mathrm{ng} / \mathrm{mL}$ (65\% sensitivity and $68.3 \%$ specificity). Positive predictive value was calculated as $67.2 \%$ and negative predictive value was calculated as $66.1 \%$ (Table 3 ). 


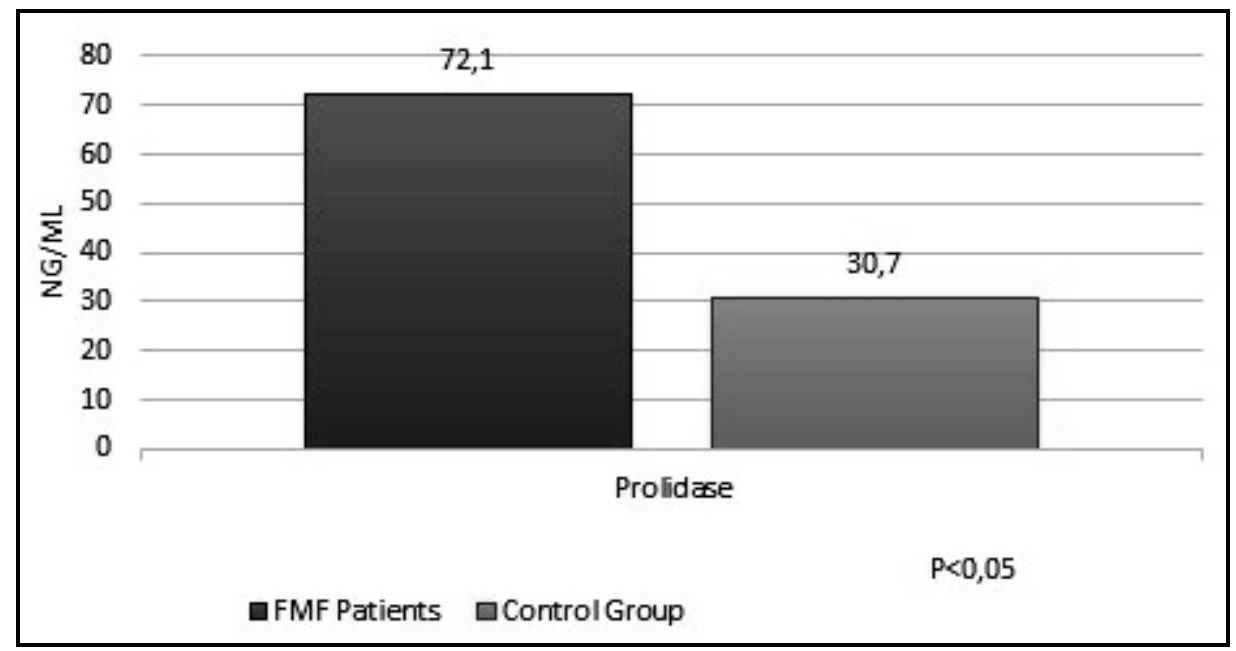

Figure 1. Serum levels of prolidase.

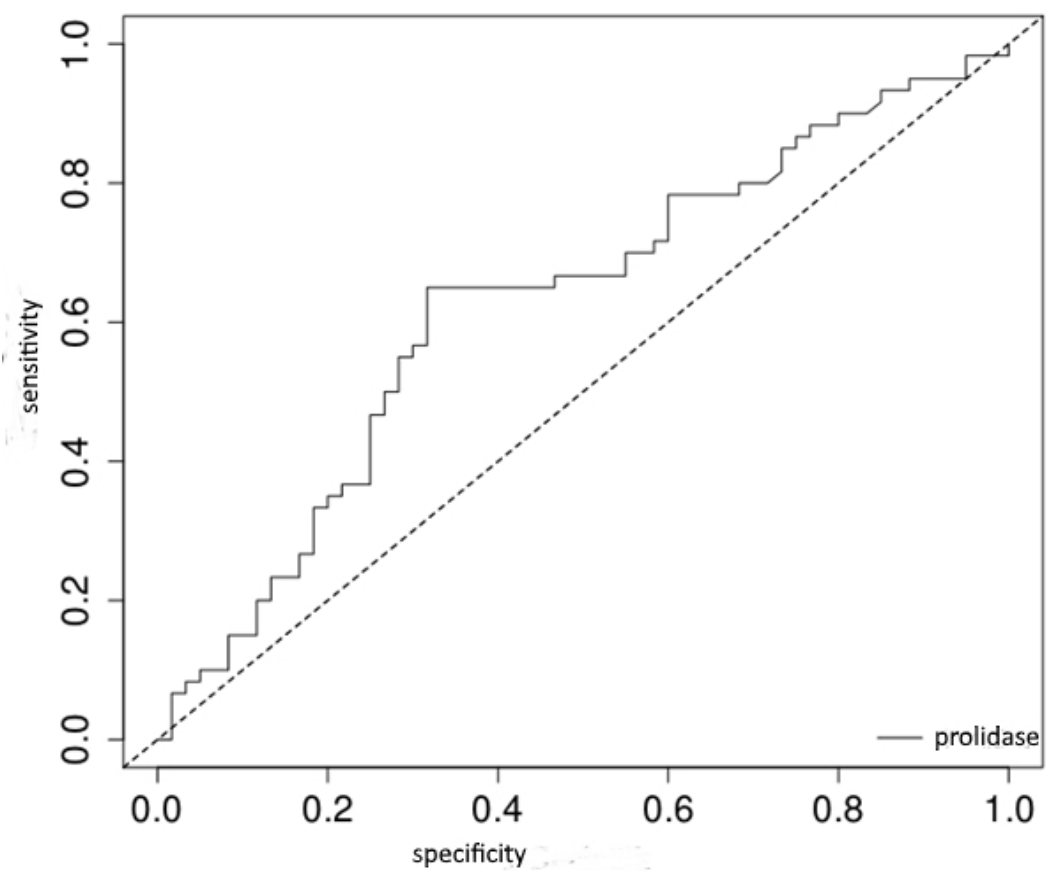

Figure 2. ROC curve analyses of serum prolidase levels.

Table 3

ROC analysis values

\begin{tabular}{|c|c|c|c|c|c|c|}
\hline \multirow{2}{*}{ Marker } & \multicolumn{2}{|c|}{ ROC statistics } & \multicolumn{4}{c|}{ Diagnostic statistics } \\
\cline { 2 - 7 } & AUC & $p$ & Sensitivity (\%) & Specificity (\%) & $\begin{array}{c}\text { Positive } \\
\text { predictive value } \\
(\%)\end{array}$ & $\begin{array}{c}\text { Negative } \\
\text { predictive value } \\
\text { (\%) }\end{array}$ \\
\hline Prolidase $>\mathbf{5 4 . 3} \mathbf{~ n g / m L}$ & $0.625(0.524-0.727)$ & 0.015 & $65.0(51.6-76.9)$ & $68.3(55.0-79.7)$ & $67.2(53.8-78.6)$ & $66.1(52.8-78.1)$ \\
\hline
\end{tabular}

AUC: Area Under Curve, ROC: Receiver Operating Characteristic. Diagnostic statistics were shown with 95\% confidence intervals.

COMPARISON OF FMF PATIENT SUBGROUPS ACCORDING TO PRAS DISEASE SEVERITY SCORING

In the FMF group, according to the severity scoring system recommended by Pras et al [8]. 39 subjects with mild disease, 17 subjects with mild-to-moderate disease and 4 subjects with severe disease were included in the study. There was no significant difference among the prolidase levels and disease severity groups. HIF-1 $\alpha$ levels were significantly higher only in individuals with severe disease activity compared to other groups $(p=0.02)$ 
(Table 4 and Table 5). There was no significant difference between Prolidase and HIF-1 $\alpha$ values in terms of clinical features and gene mutations $(p>0.05)$.
There was no correlation between acute phase reactants (CRP, ESR) and prolidase or HIF- $1 \alpha$ levels $(\mathrm{r}<0.25)$.

Table 4

Prolidase and HIF-1 $\alpha$ levels by PRAS score

\begin{tabular}{|l|c|c|c|c|}
\hline & Mild disease $(\boldsymbol{n}=\mathbf{3 9})$ & $\begin{array}{c}\text { Mild-to-moderate } \\
\text { disease }(\boldsymbol{n}=\mathbf{1 7})\end{array}$ & \multicolumn{1}{|c|}{ Severe disease $(\boldsymbol{n}=\mathbf{4})$} & $\boldsymbol{p}$ \\
\hline Prolidase $(\mathbf{n g} / \mathbf{m L})$ & $73.03(8,04-185,61)$ & $56.7(13.04-154.16)$ & $57.28(14.95-151.86)$ & 0.844 \\
\hline HIF-1a(pg/mL) & $477.0(87.0-8587.0)$ & $387.0(157.0-8787.0)$ & $7137.0(6687.0-8087.0)$ & 0.03 \\
\hline
\end{tabular}

Table 5

Post hoc analyses

\begin{tabular}{|c|c|c|c|c|c|}
\hline & Group (I) & Group (J) & Mean Difference (I-J) & Std. Error & $p$ \\
\hline \multirow{3}{*}{ HIF-1a } & 1 & $\begin{array}{l}2 \\
3 \\
\end{array}$ & $\begin{array}{l}-543.81599 \\
-5557.05128^{*}\end{array}$ & $\begin{array}{l}856.24020 \\
1546.78621 \\
\end{array}$ & $\begin{array}{l}1.00 \\
\mathbf{0 0 0 2}\end{array}$ \\
\hline & 2 & $\begin{array}{l}1 \\
3\end{array}$ & $\begin{array}{l}543.81599 \\
-5013.23529^{*}\end{array}$ & $\begin{array}{l}856.24020 \\
1637.24455\end{array}$ & $\begin{array}{l}1,00 \\
.010\end{array}$ \\
\hline & 3 & $\begin{array}{l}1 \\
2 \\
\end{array}$ & $\begin{array}{l}5557.05128^{*} \\
5013.23529^{*}\end{array}$ & $\begin{array}{l}1546.78621 \\
1637.24455 \\
\end{array}$ & $\begin{array}{l}.002 \\
.010 \\
\end{array}$ \\
\hline \multirow{3}{*}{ Prolidase } & 1 & $\begin{array}{l}2 \\
3 \\
\end{array}$ & $\begin{array}{l}7.83778 \\
9.63731 \\
\end{array}$ & $\begin{array}{l}15.14193 \\
27.35368 \\
\end{array}$ & $\begin{array}{l}1.0 \\
1.0 \\
\end{array}$ \\
\hline & 2 & $\begin{array}{l}1 \\
3\end{array}$ & $\begin{array}{l}-7.83778 \\
1.79954\end{array}$ & $\begin{array}{l}15.14193 \\
28.95337\end{array}$ & $\begin{array}{l}1.0 \\
1.0\end{array}$ \\
\hline & 3 & $\begin{array}{l}1 \\
2\end{array}$ & $\begin{array}{l}-9.63731 \\
-1.79954 \\
\end{array}$ & $\begin{array}{l}27.35368 \\
28.95337 \\
\end{array}$ & $\begin{array}{l}1.0 \\
1.0\end{array}$ \\
\hline
\end{tabular}

Group 1: Mild disease, Group 2: Mild-to-moderate disease, Group 3: Severe disease

${ }^{*}$ The mean difference is significant at the 0.05 level.

\section{DISCUSSION}

Prolidase is significant in many physiological and pathophysiological processes, such as wound healing, inflammation and angiogenesis, by regulating the collagen metabolism, and expression of growth factors and transcription factors. Prolidase activity increases when the collagen cycle accelerates [9]. Prolidase level has been studied in various diseases (Behçet's Disease (BD), Pulmonary Tuberculosis, various cancers, Rheumatoid Arthritis (RA), etc.). When literature is reviewed, Serum Prolidase Activity (SPA) was found to be higher in patients with BD compared to healthy controls in a study conducted by Bozkurt et al. In has been found that increased angiogenesis and inflammation, prolidase increase may be associated with an increase in HIF-1 $\alpha$ and Vascular Endothelial Growth Factor (VEGF) levels in the pathophysiology of $\mathrm{BD}$ [10]. In our study, serum prolidase level was higher in FMF group than in healthy control group. In other rheumatological diseases, there are also studies in which the exact opposite results were obtained. For example, in the study of Uçar et al. which included Ankylosing Spondylitis (AS), RA and healthy control groups, SPA was found to be lower in both patient groups compared to the control group [11]. It was stated that the low level of SPA in these diseases may be related to irregularities in collagen turnovers and decreased physical activity levels of these patients [11]. There are studies suggesting that SPA is correlated with the evaluation of treatment response in disease follow-up and disease activity scores in patients with AS. In rheumatic diseases, it has been stated that low SPA may be due to ineffective collagen turnover and poor quality of bone and may be related to decreased levels of physical activity of these patients [12]. Çelik et al. determined that SPA was lower in patients with systemic sclerosis compared to controls [13]. In these diseases, particularly collagen and bone turnovers are impaired. In particular, this suggests that prolidase level is not a marker of chronic inflammation in these patients, but rather that prolidase has different effects on bone turnover. FMF is a disease in which the bone turnover is not actually much affected and that acute/chronic inflammation is more prominent. Therefore, our study showed different results compared to the abovementioned RA and AS studies. In cases of acute infection, for example in patients with pulmonary tuberculosis (PTB), the SPA was higher than healthy controls and correlated with acute phase reactants [14]. Since PTB has both acute and chronic process of inflammation, it was stated that collagen degradation increased in response to inflammation. For this reason, it has been suggested that SPA may be 
considered among the acute phase reactants [14]. In our study, the use of prolidase as an attack marker could not be evaluated since the number of patients with acute inflammation, i.e. number of patients in FMF episodes is low. This is one of the limitations of our study. However, the high levels of prolidase may indicate a persistent subclinical inflammation or chronic inflammation in patients with FMF. There was a paradoxical decrease in prolidase according to PRAS scoring. This was not statistically significant, but it was a remarkable feature, although it could not be fully evaluated because of the small number of patients.

Helper T cells, T-reg and dendritic cells are critical in the pathogenesis of autoimmune diseases such as Systemic Lupus Erythematosus (SLE) and Rheumatoid Arthritis (RA), HIF1 $\alpha$ is considered to have a role in these autoimmune disorders [15]. In RA, hypoxia effects were investigated in important pathophysiological events such as synovial inflammation, angiogenesis and cartilage destruction, and it was suggested that HIF inhibitors could provide successful results in the treatment of RA [16]. However, no clinical study has been conducted in rheumatic diseases. In our study, no statistically significant difference was determined between the FMF group and the healthy control group. However, when we compare the patient groups according to the PRAS scoring, although HIF 1- $\alpha$ level was found to be significantly higher in the group with severe disease, the number of patients in this group was 4 and this caused study limitation. Nevertheless, this result suggests that the duration, severity, and complications of the disease may be related to the HIF-1 $\alpha$ level. One of the limitations of the study is the absence of serum amyloid A as comparator. The other limitation of study was the absence of patients with active attack period. If we had such a group, we would have the opportunity to show the level of these biomarkers in active inflammation.

In conclusion, our study is the first study comparing serum prolidase and HIF-1 $\alpha$ levels in FMF patients with healthy controls. Serum prolidase level was determined to be higher in FMF patients even in the attack-free period. This suggests that subclinical inflammation may persist in FMF patients even in the attack-free period. In order for serum prolidase levels to be used as a marker of subclinical inflammation and to better understand the role of HIF-1 $\alpha$ in the pathogenesis of FMF, there is a need for larger studies with more patients comparing the individuals in attack and attack-free periods with the healthy controls.

Introducere: Febra Mediteraneeană Familială (FMF) este o boală autoinflamatorie. Prolidaza este o imidodipeptidază specifică implicată în degradarea colagenului. Prolidaza joacă un rol important în inflamație și vindecarea rănilor. Factorul inductibil al hipoxiei la (Hypoxia-inducible factor-1 $\alpha$, HIF-1) este o proteină importantă în reglarea răspunsului imun, hemostază, vascularizație. Scopul studiului a fost compararea prolidazei serice și nivelului HIF-la la pacienții cu FMF în perioada de afebrilitate și în cazul unui grup de control de sănătoși.

Metode: Intre august 2017 și decembrie 2017, 60 de pacienți diagnosticați cu FMF conform criteriilor Tel-hashomer internați în Departamentul de Reumatologie al Secției de Medicină Internă arondat Universității de Medicină Sivas Cumhurivet precum și 60 de voluntari sănătoși au fost înrolați în studiu.

Rezultate: Mediana nivelului prolidazei serice a fost $72,1 \quad(25,1-114,9)$ $n g / m l$ in grupul FMF și 30,7 (21,3-86,2) $n g / m L$ in grupul sănătos de control $(p=0,018)$. Analiza ROC a obiectivat o sensibilitate de 65\% și o specificitate de $68.3 \%$ pentru o valoare serică a prolidazei de $54,03 \mathrm{ng} / \mathrm{mL}(p<0,05)$. Mediana nivelului seric al HIF-1 î in grupul FMF a fost 482,0 (292,0-3967,0) pg/mL şi $632,0(362,0-927,0) \mathrm{pg} / \mathrm{mL}$ in grupul de control de oameni sănătoși $(p>0,05) . \mathrm{Nu}$ $s$-a stabilit o asociere semnificativă statistic intre rezultatele de laborator, gen, vârstă şi prolidază $(p>0,05)$.

Concluzii: Nivelurile serice ale prolidazei în cazul pacienților FMF aflați în afara unui episod acut au fost semnificativ mai mari comparativ cu cele ale grupului de control de persoane sănătoase. Cu toate acestea, rolul prolidazei și al HIF-1 $\alpha$ în FMF rămâne să fie clarificat prin studii ulterioare extensive. 
Correspondence to: Mehmet Emin Derin, M.D. Department of Internal Medicine - Rheumatology, Cumhuriyet University Medical Faculty, 58140, Sivas, Turkey

E-mail: eminderin@gmail.com Phone: +90-346-258 0949

Conflict of interest disclosure: The authors declare that they have no conflicts of interest.

Acknowledgements: This study was supported by Cumhuriyet University Scientific Research Projects (CUBAP) Commission (Project Number: T-744)

\section{REFERENCES}

1. OZEN S, KONE-PAUT I, GÜL A. Colchicine resistance and intolerance in familial mediterranean fever: Definition, causes, and alternative treatments. Semin Arthritis Rheum. 2007; 47(1):115-20.

2. PROCOPIO V, MANTI S, BIANCO G, CONTI G, ROMEO A, MAIMONE F, et al. Genotype-phenotype correlation in FMF patients: A "non classic" recessive autosomal or "atypical" dominant autosomal inheritance? Gene. 2018; 641:279-86.

3. YANG L, LI Y, DING Y, CHOI K-S, KAZIM AL, ZHANG Y. Prolidase directly binds and activates epidermal growth factor receptor and stimulates downstream signaling. J Biol Chem. 2013; 288(4):2365-75.

4. SEZER U, ERCIYAS K, ÜSTÜN K, PEHLIVAN Y, ZIYA ŞENYURT S, AKSOY N, et al. Effect of Chronic Periodontitis on Oxidative Status in Patients With Rheumatoid Arthritis. J Periodontol. 2013; 84(6):785-92.

5. MENG X, GRÖTSCH B, LUO Y, KNAUP KX, WIESENER MS, CHEN X-X, et al. Hypoxia-inducible factor-1 $\alpha$ is a critical transcription factor for IL-10-producing $B$ cells in autoimmune disease. Nat Commun. 2018; 9(1):251.

6. PENG J, SHEN S, WANG J, JIANG H, WANG Y. Hypoxia-inducible factor 1- $\alpha$ promotes colon cell proliferation and migration by upregulating AMPK-related protein kinase 5 under hypoxic conditions. Oncol Lett. 2018; 15(3):3639-3645.

7. WU J, CUI H, ZHU Z, WANG L, LI H, WANG D. Effect of HIF1 $\alpha$ on Foxp3 expression in CD4 + CD $25-T$ lymphocytes. Microbiol Immunol. 2014; 58(7):409-15.

8. PRAS E, LIVNEH A, BALOW JE JR, et al. Clinical differences between North African and Iraqi Jews with familial Mediterranean fever, Am J Med Genet. 1998 ;75: 216-9

9. ARE VN, KUMAR A, KUMAR S, GOYAL VD, GHOSH B, BHATNAGAR D, et al. Crystal structure and biochemical investigations reveal novel mode of substrate selectivity and illuminate substrate inhibition and allostericity in a subfamily of Xaa-Pro dipeptidases. Biochim Biophys Acta - Proteins Proteomics. 2017; 1865(2):153-64.

10. BOZKURT M, YÜKSEL H, EM S, OKTAYOGLU P, YILDIZ M, AKDENIZ D, et al. Serum prolidase enzyme activity and oxidative status in patients with Behçet's disease. Redox Rep. 2014; 19(2):59-64.

11. UÇAR D, EM S, BOZKURT M, OKTAYOGLU P, YÜKSEL HK, ÇAGLAYAN M, et al. Serum Prolidase Activity in Ankylosing Spondylitis and Rheumatoid Arthritis. Clin Med Insights Arthritis Musculoskelet Disord. 2013; 6: $29-33$.

12. BASPINAR S, KIRNAP M, BASPINAR O, DIZDAR OS, KOCER D. Serum prolidase level in ankylosing spondylitis: low serum levels as a new potential gold standard biomarker for disease activity. Rheumatol Int. 2016; 36(11):1609-16.

13. CELIK A, BIRER MN, KILINC M. Serum prolidase activity in systemic sclerosis. Clin Rheumatol. 2017; 36(8):1827-32.

14. GUMUS S, YAMAN H, OZCAN O, DENIZ O, KARAMAN B, CAKIR E, et al. Serum prolidase activity in patients with pulmonary tuberculosis. Scand J Clin Lab Invest. 2011; 71(6):467-72.

15. YANG Z-C, LIU Y.Hypoxia-Inducible Factor-1 $\alpha$ and Autoimmune Lupus, Arthritis. Inflammation. 2016; 39(3):1268-73.

16. BRUNO A, HABIB A, HUA S, DIAS TH. Hypoxia-Inducible Factor (HIF) as a Target for Novel Therapies in Rheumatoid Arthritis. Front Pharmacol Front Pharmacol. 2016; 7:18.

Received October $2^{\text {nd }} 2019$ 